\title{
A Geospatial Analysis of Mycenaean Habitation Sites Using a Geocumulative versus Habitation Approach
}

\author{
George Malaperdas, Nikolaos Zacharias \\ Department of History, Archaeology and Cultural Resources Management, University of the Peloponnese, Kalamata, Greece \\ Email: envcart@yahoo.gr
}

How to cite this paper: Malaperdas, G. and Zacharias, N. (2018) A Geospatial Analysis of Mycenaean Habitation Sites Using a Geocumulative versus Habitation Approach. Journal of Geoscience and Environment Protection, 6, 111-131.

https://doi.org/10.4236/gep.2018.61008

Received: December 23, 2017

Accepted: January 27, 2018

Published: January 30, 2018

Copyright ( 92018 by authors and Scientific Research Publishing Inc. This work is licensed under the Creative Commons Attribution International License (CC BY 4.0).

http://creativecommons.org/licenses/by/4.0/

\begin{abstract}
In this study GIS and spatial analysis were applied in order to thoroughly examine possible relationships between the location of Mycenaean $\left(16^{\text {th }}-11^{\text {th }}\right.$ c. BC) settlements in Messenia and the geomorphological characteristics of the area of their establishment. The idea lying behind this attempt is that the Mycenaeans would not have established their habitation sites randomly but according to decisive criteria, among which geomorphological characteristics played an important role. Such criteria include land aspect, terrain slopes, the hydrographic network and the geology of the area, all significant factors which need to be taken into consideration in order to evaluate the choice of settlement establishment. The combination of all available geological and environmental data with archaeological records provides a better view of the way local environments were built up in the past in association with the human site exploration and habitation; this view, hereafter defined as the Geocumulative versus Habitation $(\mathrm{GCH})$ approach, constitutes the axis of the present study. The results of the study show a clear tendency in choosing settlement locations according to GCH criteria, resulting in a preference for flat to low-lying ground, in an environmentally friendly orientation (with environmental conditions such as protection from the north wind and at the same time profit by the sunlight), facilitating exploitation of local geological resources and of the hydrographic network.
\end{abstract}

\section{Keywords}

GIS, Environmental Parameters, Mycenaean Era, Messenia Greece, Site Location

\section{Introduction}

Messenia is considered one of the most important Mycenaean regions of Greece 
due to the great number and the importance of Mycenaean sites identified. Habitation remains, surface finds, vaulted and chamber tombs are constantly being added to the archaeological index of the region, with 149 sites verified (Figure $1)$.

Geospatial analysis applies statistical analysis using information science techniques such as Geographic Information Systems (GIS) and geomatics on data with a geographic or geospatial component. More specifically, the increased use of GIS technologies and approaches in archaeology and cultural landscape studies over the last decades has yielded unique information [1] [2]. The present paper demonstrates the importance of the application of GIS and spatial analysis in mapping the Mycenaean habitation sites.

Archaeology was one of the first to exploit the potential using GIS in landscape studies and cultural heritage management [3]. Archaeologists are often considered as frontrunners within the social sciences and humanities in employing GIS [4]. By fusing archaeological and environmental data in a GIS-based system it is possible to study landscapes at regional and local scale. Comprehensive modeling of diachronic settlement patterns can be provided by using site catchment, proximity and viewshed analysis. Moreover, the theoretical background of archaeological research can be revised or even modified by GIS [5]. For example Dederix (2017) created a cost-dependent terrestrial movement pattern via cost surface analyses based on examining the geomorphology of the area and the locations of circular tombs and settlements [6]. Alexakis et al. (2013) focused on the creation of a risk assessment model for the archaeological sites of the area of Cyprus [7]. In another example De Reu et al. (2013) created an algorithm called topographic position index, which was first applied in northwest Belgium, and was used to measure topographic slope positions and to automate landform classifications [8]. Also Ladefoged et al. (2011) used the analysis of LiDAR data to enable a more precise and accurate assessment of human activities in the field system, focusing on the area of Hawai'i Island [9].

Nowadays, GIS programs are increasingly used in archaeology science for storage, management, analysis and presentation of results. The development of concepts, approaches and tools that can help us to understand the human interaction with the spatial world in the past remains a real challenge for archaeological GIS research [10]. In the future, the use and the importance of GIS technologies will increase further, as new GIS applications will be capable of more complicated forms of analyses. New tools are now being developed for 3D representations, network analyses, mobile technologies and virtual reality with increased emphasis on interactivity [5]. In addition, online archives allow the databases to be more freely exchanged [10]. It is certain that the use of GIS in current and future archaeological surveys as well as in cultural heritage management will continue to grow. In this paper we present the Geocumulative versus Habitation approach $(\mathrm{GCH})$, which is an attempt to collect and associate the geological and environmental characteristics of the studied Mycenaean habitation sites with availa- 
ble archaeological record. The basic parameters under study are: 1) the morphology FMr (elevation, slope and aspect); 2) the microclimate Fcl (sunshine and shelter from wind); and 3) the geology Fgl (geological formations, hydrographic network) of a region. Given the cumulative significance of the above mentioned parameters, a more holistic hypothesis can be formulated regarding the distribution of the Mycenaean habitation sites in Messenia.

The aforementioned approach can provide combined information on the criteria used by the Mycenaeans in the selection of their settlement location. Therefore, it can contribute to a nuanced study of site location, in connection to varied parameters of the Mycenaean life, like political organization, economy, social structure and symbolism.

\section{Materials and Methods}

Field survey, statistical and spatial analysis as well as image processing of satellite images and DEM's data were carried out on the eighteen most extensive Mycenaean settlements of Messenia, according to excavation data or surface finds. The river Neda constitutes the conventional northern frontier of the region under study [12] [13]. Neda is still used today as the boundary between the Prefectures of Messenia and Elis (Figure 1).

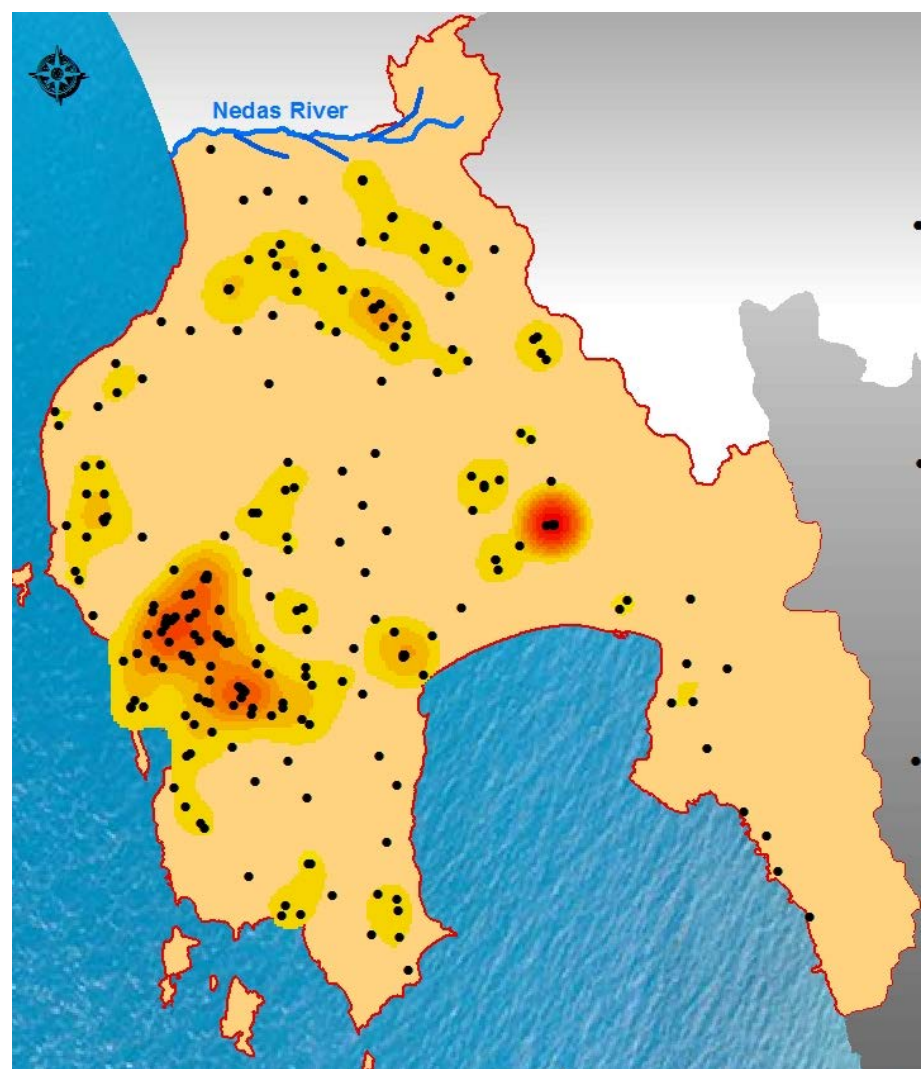

Figure 1. The Messenia Prefecture with the 149 Mycenaean sites indicated as black points. The density of the sites (Kennel density) is presented in a colour range of red (most dense) to yellow (least dense). 


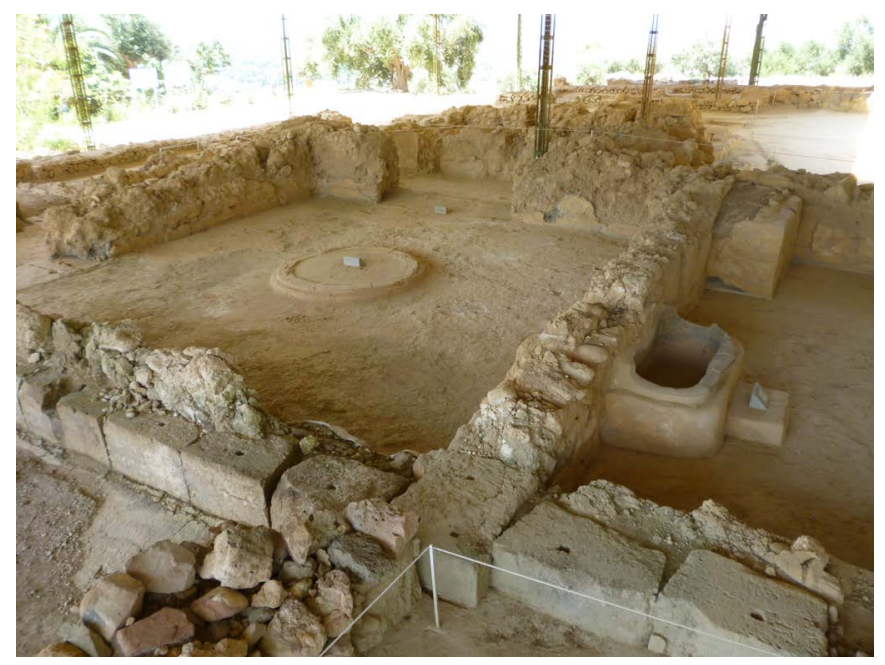

Figure 2. Ano Eglianos (Nestor's Palace).

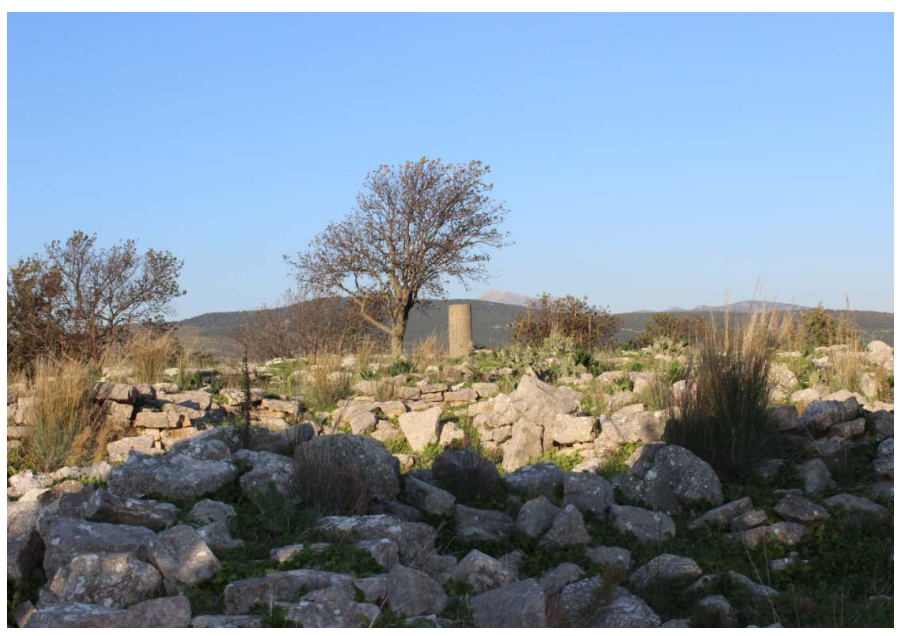

Figure 3. Acropolis of Malthi.

The settlements under study correspond to the two upper tiers of the four tier settlement hierarchy schema established in the study of Mycenaean settlement patterns and distribution. For example, Bintliff (1977) speaks of 1) super centers, 2) mayor centers, 3) second-scale villages, and d) farms or hamlets, correlating the extent of settlement debris with the existence of elaborate or large scale architecture, of fortifications, of tholos or chamber tombs, and of Linear B archives [14]. This schema has also broadly been applied in the case of Messenia, with the two first tiers of settlement hierarchy considered to represent primary and secondary order centers [12] or towns and large villages [13]. Cosmopoulos distinguishes: 1) the palace at Ano Englianos (Figure 2) from, 2) second-order centers, like Iklaina, and Malthi (Figure 3), 3) smaller villages, and 4) farmsteads or rural installations [15] while Hope Simpson, in his recent discussion of the kingdom of Pylos, emphasizes settlement size as a criterion of distinguishing among 1) towns, to which Ano Englianos is included, 2) large villages, larger than 2.5 ha, 3) villages, larger than $1.0 \mathrm{ha}, 4$ ) hamlets, between 0.5 and $1.0 \mathrm{ha}$, and 5) farms, 
less than 0.5 ha. [13]. It must be noted, however, that, in order to include each settlement in one or the other category, relevant studies usually combine estimated settlement size with other criteria, such as the existence of architectural remains and the types of existing nearby tombs. Moreover, as far as Messenia is concerned, settlement hierarchy is inevitably related to the study of the political geography of the region, based on the interpretation of toponyms and other relevant information included in the Linear B tablet archive of Ano Englianos [12] [13] [15] [16].

In this paper, settlement size beyond 3.0 ha, as inferred by excavation or survey data, is the main criterion applied to the selection of the settlements discussed. This criterion broadly corresponds to the two upper tiers of the settlement hierarchy schema mentioned above, setting a stricter size limit for the inclusion of a settlement in the second category. Additionally, the existence of tholos tombs in the vicinity of some of these settlements is taken into account as a secondary criterion for including them in the present study [13] [17] [18] [19] [20] [21].

In order to estimate the coordinates of each site of interest with the highest possible accuracy, we visited the vast majority of the sites and acquired the exact location (via GPS) using the Greek Geodetic Reference System (EGSA '87). In addition, satellite images of high resolution were used (Quickbird 0.6 pixel and IKONOS $1 \mathrm{~m}$ ). The correction of some minor deviations noted lead to the formation of a database of highly accurate points.

The topographic maps of the Geographical Service of the Greek Army and the Geologic maps of IGME were digitized to illustrate the characteristics of the surface of Messenia. Combining these digitized maps with satellite images, we created a digital high precision county elevation model, with a cell size at $20 \mathrm{~m}$. This model was used to create the Digital Terrain Model (DTM, the slope, the aspect and the settlement intervisibility maps (Figure 4). Additionally, geological rocks were reclassified (e.g. limestone Jurassic and Cretaceous limestone unified in one category) and other elements of the initial maps, such as faults, rivers and lakes were also digitized.

Finally, based on various spatial analyses in the GIS, individual characteristics of the ground in the vicinity of the settlements in question were studied, in order to examine the likely associations between settlement location and morphological parameters such as 1) land and terrain slopes, 2) the hydrographic network (distance from water by creating Buffer Zones), 3) the geology of the area, and 4) the aspects of the land. The Geocumulative versus Habitation approach is expected to greatly improve our understanding of the habitation criteria of the Mycenaean people (Figure 5).

\section{Results}

Modern geoarchaeological studies adopt a holistic approach towards the evolution and use of local environments by combining landscape morphology with 

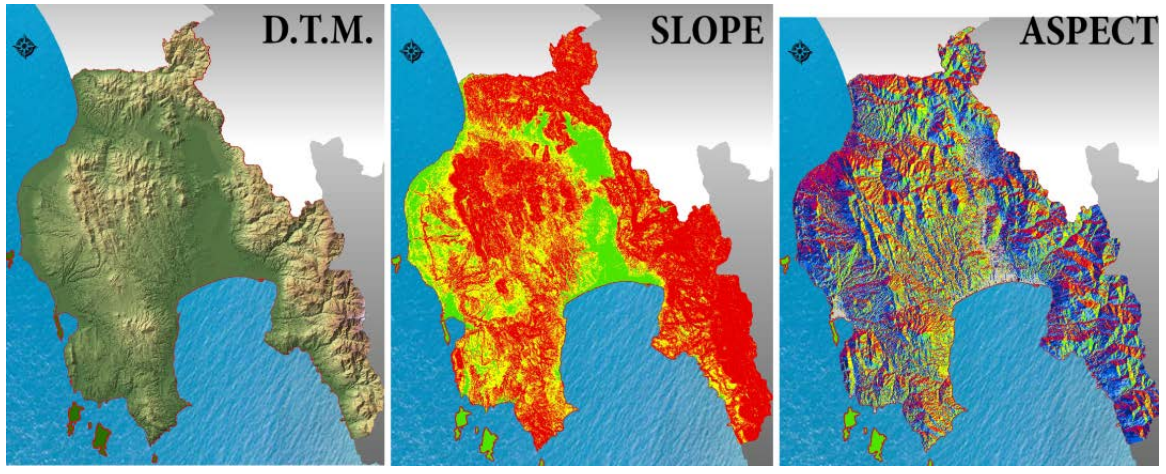

Figure 4. Extraction from digital elevation model (from left to right-DTM, Slope, Aspect).

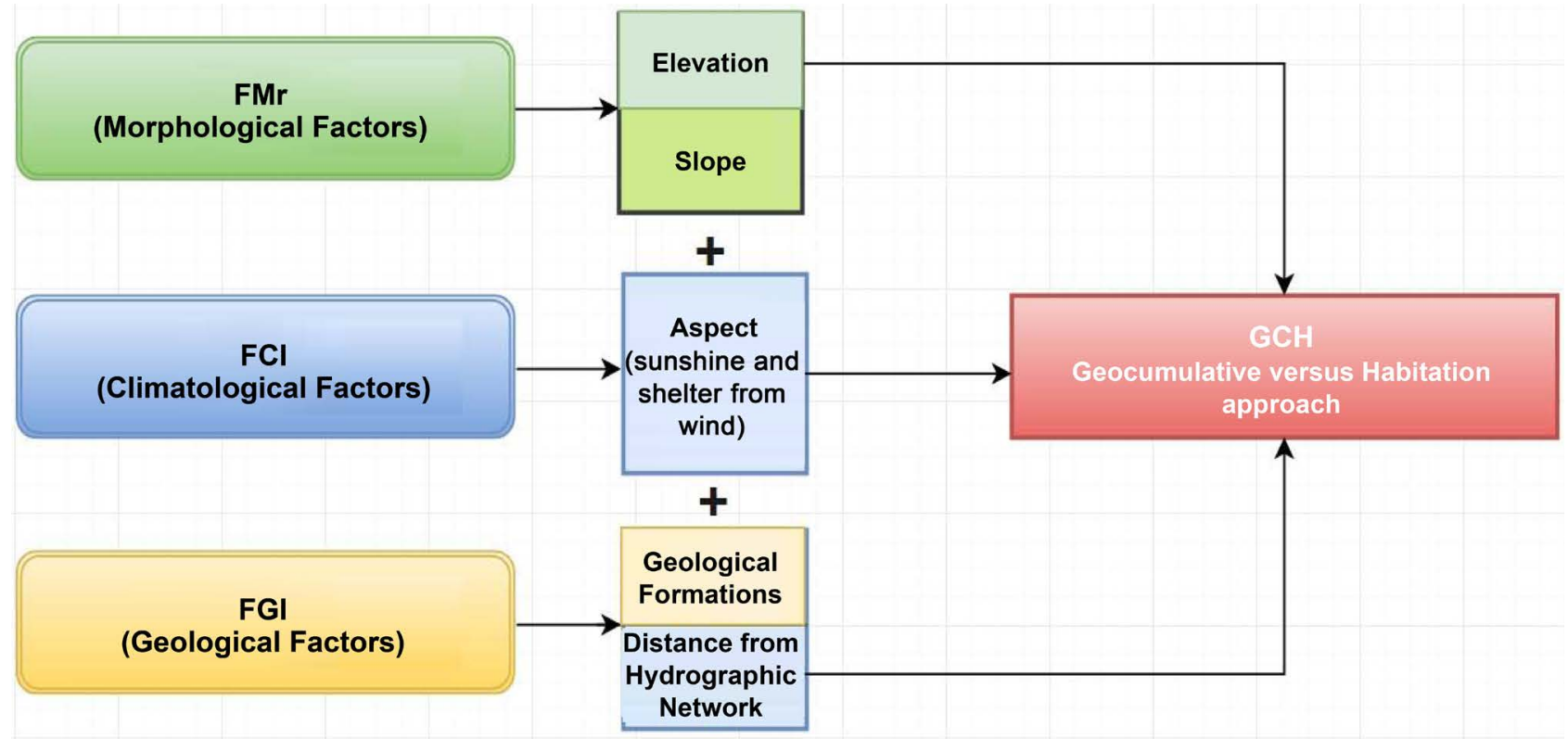

Figure 5. Methodology adopted (Geocumulative versus Habitation Theory).

environmental and cultural parameters, like soil fertility, water supply, air quality, human health and habitation [22] [23]. The aim of the present study is to analyze the geomorphological, geological and climatic parameters prevailing in the locations mentioned in Table 1 and to diagnose the presence of common features of the used parameters.

According to the selection criteria stated above, 18 Mycenaean settlements were examined. The size of each settlement and the presence of tholos tombs in the area are presented in Table 1; However, Figure 6, shows the location of each settlement. ${ }^{1}$

\subsection{Elevation}

Messenia Prefecture has a peculier geomorphological formation. The western

${ }^{1}$ For the location of the settlements under study in Messenia see Hope Simpson 2014 [13], 1981 [20]; Banou 2012 [21], McDonald and Rapp, 1972 [24]. 
Table 1. Settlement index (beginning from Ano Eglianos and moving southwards, in a counter-clockwise direction).

\begin{tabular}{|c|c|c|}
\hline SETTLEMENTS & SIZE $\left(\right.$ Hectares $\left.^{b}\right)$ & THOLOS \\
\hline 1. Ano Eglianos & 18 (page 20) & $Y E S$ \\
\hline 2. Koryfasion-Beylerbey & 3.5 (page 20$)$ & $Y E S$ \\
\hline 3. Iklaina & 12 (page 20) & $N O$ \\
\hline 4. Koukounara & $0.9($ page 21$)$ & $Y E S$ \\
\hline 5. Yialova-Palaiochori & $5.4($ page 21$)$ & $N O$ \\
\hline 6. Metaxada-Kalopsana & 3 (page 22) & $N O$ \\
\hline 7. Rizomylos-Nichoria & 5 (page 25) & $Y E S$ \\
\hline 8. Thouria-Ellinika & $6($ page 26$)$ & $Y E S$ \\
\hline 9. Pidima-Ayios Ioannis & 4 (page 26$)$ & $N O$ \\
\hline 10. Kalamata-Kastro & 3 (page 26) & $N O$ \\
\hline 11. Kardamyli-Kastro & 3.7 (page 27) & $N O$ \\
\hline 12. Stoupa-Ancient Lefktro & 5 (page 27) & $N O$ \\
\hline 13. Kato Melpeia-Krebeni & 4.5 (page 27) & $N O$ \\
\hline 14. Malthi-Gouves & 3 (page 28) & $Y E S$ \\
\hline 15. Dorio-Kontra & 30 (page 28) & $N O$ \\
\hline 16. Filiatra-Ayios Christoforos & 4.5 (page 23) & $N O$ \\
\hline 17. Myron-Peristeria ${ }^{c}$ & 2 (page 23) & $Y E S$ \\
\hline 18. Mouriatada-Elliniko & 3 (page 23) & $Y E S$ \\
\hline
\end{tabular}

${ }^{a}$ The habitation site of Koukounara is significantly smaller than 3 ha; however the site is included in the settlements under study due to the large number of tholos tombs unearthed in the wider area (Hope Simpson 2014:21 [13]; Hope Simpson 1981:119 [20]; Banou 2012: 57-59) [21]; ' $S e e$ Hope Simpson 2014 [13]; 'The site is smaller than $3 \mathrm{ha}$; however it is considered important due to the five tholos tombs unearthed in its immediate vicinity (Hope Simpson 2014:23 [13]; Hope Simpson 1981:121 [20]; Banou 2012: 57-59) [21].

coasts of the Ionian Sea with lowlands and small hills are interrupted by high mountains as we proceed further to the hinterland. Continuing to the east, the vast plain of the Stenyklarion field descends to the south and to the Messinian Gulf. To the eastern parts of the prefecture, near the boundaries with the prefecture of Laconia we find the highest altitudes in the Taygetos Mountain. The elevation of Messenia Prefecture can be divided in four categories:

1) Areas with low altitude $(0-300 \mathrm{~m}$.) represent the lowland areas as well as the majority of the small hills.

2) Areas with altitude of $300-600 \mathrm{~m}$. represent the hills located mainly at the foot of the great mountains.

3) Areas with altitude of $600-1200 \mathrm{~m}$. represent the semi mountainous areas.

4) Areas with altitude of $1200-2400 \mathrm{~m}$. represent the mountainous areas.

For the greater understanding of Messenian topography it is observed that the terrain from 0 - 300 meters constitutes $48 \%$ of the total study area. Correspondingly, rates for grounds from $300-600$ (26\%), $600-1200$ (21\%) and $1200-$ 2400 (5\%) are observed (Figure 7). 


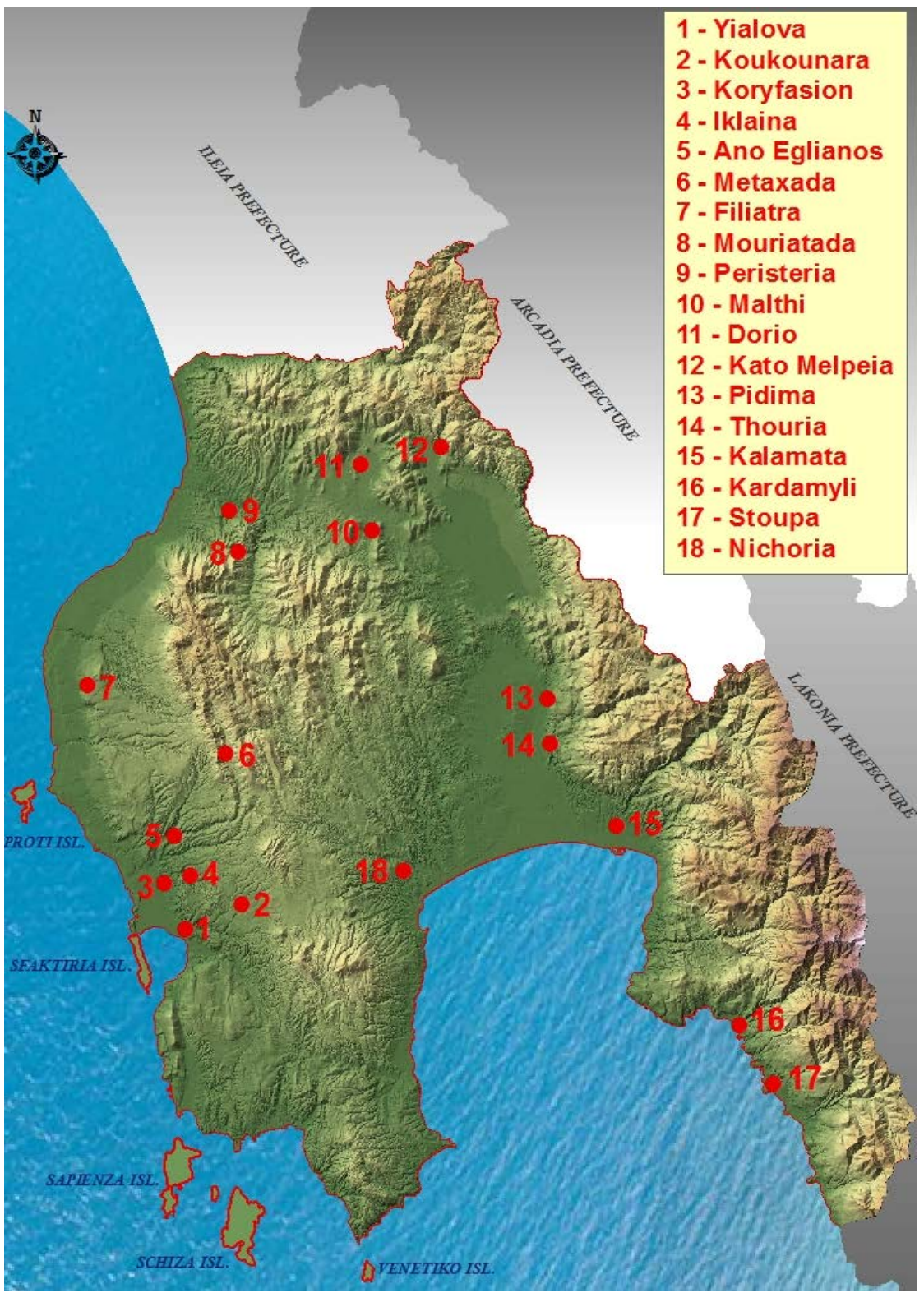

Figure 6. Messenian Mycenaean settlements under study.

All locations are located in small altitudes or hills, representing only the first two elevation categories. The maximum observed altitude is 465 meters in the area of Metaxada and the minimum altitude is 23 meters in the plain of Kardamili. Based on the topography of the sites the settlements could also serve as observatories, providing high territorial control, since they are located in small hills and they have a significant radius of visibility.

A total of $39 \%$ of all settlements are located at ground level (flat land). The majority (83\%) are on hills of low altitude $(0-300 \mathrm{~m})$, i.e. in the areas forming the plains and the small hills of Messinia. The remaining $17 \%$ are located on higher hills. None of the settlements are located at an altitude greater than $465 \mathrm{~m}$ (Figure 8 \& Table 2). 


\section{Elevation (m)}

$\square 0-300 \square 300-600 \square 600-1200 \square 1200-2400$

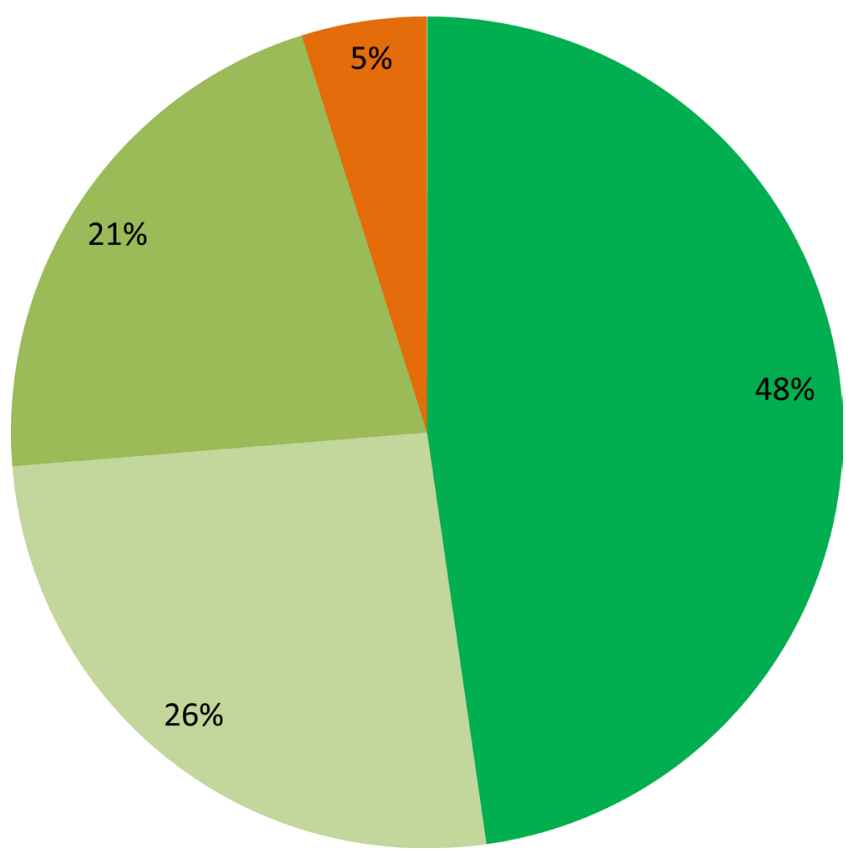

Figure 7. Elevation of the entire Messenia Prefecture.

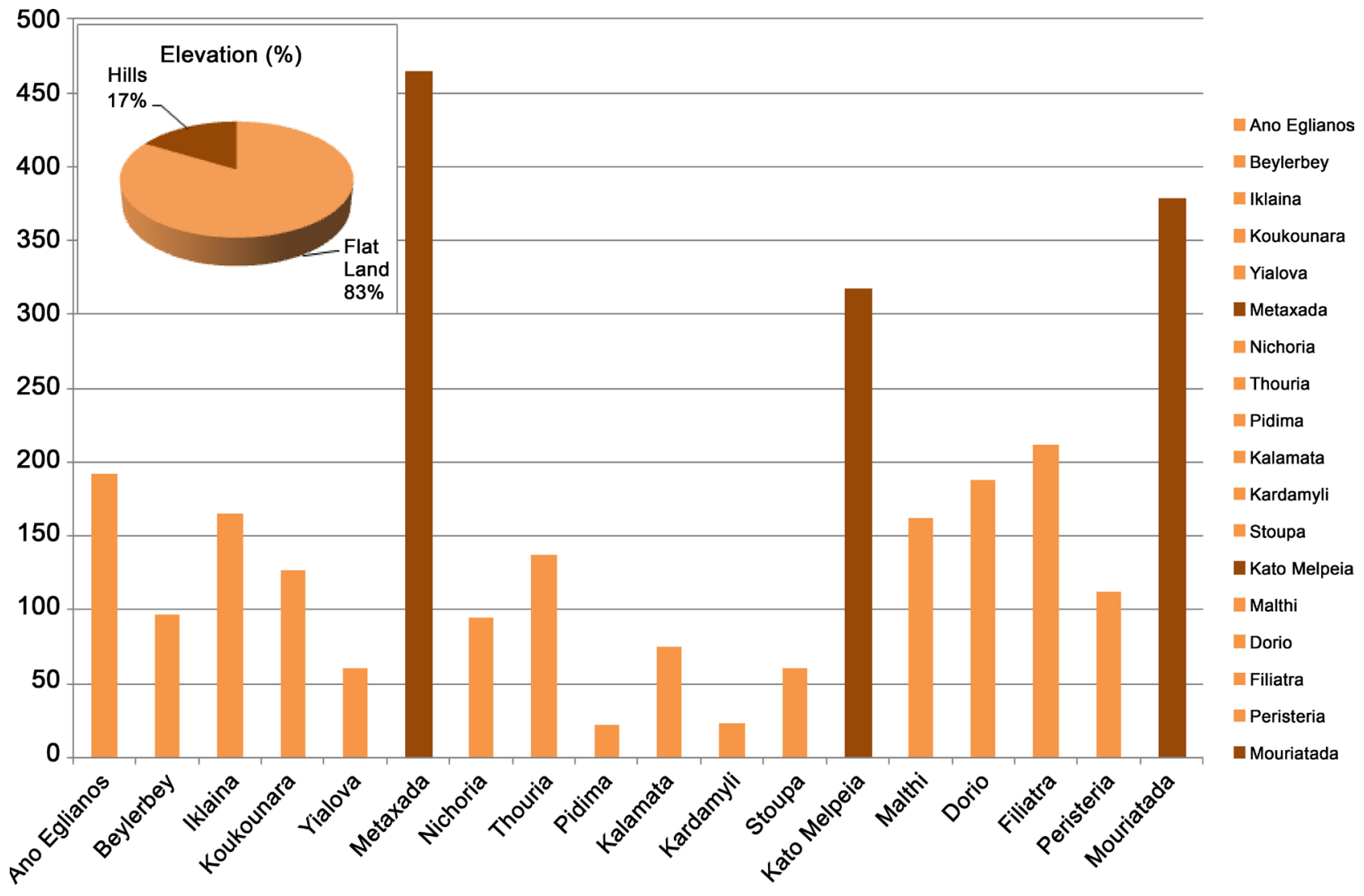

Figure 8. Association of elevation with settlement location. 


\subsection{Terrain}

Slope Calibration: For the calibration of the slopes category we used the protocol suggested by Demek [25]. According to this protocol the results were classified in six categories of slope angles. The first category has a slope (Little or None: $0 \%-3.5 \%$ ) and the terrain is characterized by a little or none to slightly inclined relief (areas with high floodplains, leveling surfaces and terraces). The second category with slope (Gentle: $3.5 \%-8.7 \%$ ) is characterized as a slightly inclined relief (valleys, dune slopes). The third class with gradients (Moderate: 8.7\% $26.8 \%$ ) shows soils with a strong inclined relief (valleys, tectonic terraces). In the fourth category (Steep: $26.8 \%-70 \%$ ) the terrain is characterized as a steep to extremely sharp relief (mid-valley slopes). The fifth category with gradients (Extremely Steep: $70 \%-135 \%$ ) is characterized by a steep relief (with steep slopes of high valleys, canyon slopes). Finally, in the last category the slopes exceed 135\% (Excessively Steep: $>135 \%$ ) and the relief is characterized as vertical (with vertical slopes in mountain areas).

For the needs of the present study it was deemed unnecessary to describe slope in such detail and the categories were reclassified from the original based on newer studies. So the extreme values (with the first two categories) and the last two have created a new classification as their general characteristics, quantitative and descriptive, are very similar. So we have the Low class: with values of $0-8.7$ that characterize smooth surfaces and Semi-class: with values of $8.7-26.8$, which characterize the steepest surfaces.

The association between the slopes of the ground and the location of settlements is shown in Figure 9 and Table 2. All the examined settlements are located on low slope terrain and in soils generally designated as lowlands. More specifically, $72 \%$ of all settlements are located on low slope terrain; the remaining $28 \%$ are located on medium slope terrain (semi-steep). These lands are most suitable for habitation and would have been easily accessible for the inhabitants of the time.

\subsection{Aspect}

The climatic conditions that prevail in an area are significant factors affecting the residential development. Grounds with southern orientation in general create a shelter of bioclimatic factors, protecting from northern winds and ensuring maximum conditions of sunshine and temperature. The results of the present analysis show that all settlements are oriented to the South, Southeast and Southwest presumably in order to be protected from the north wind and at the same time profit by the sunlight (Figure $10 \&$ Table 2). It is remarkable that none of the examined settlements is oriented to a North, East or West ground, despite the fact that only $40 \%$ of the entire Messenia Prefecture are located in south grounds orientation (Figure 11).

\subsection{Geology}

The geology of the region also appears to play a major role in the selection of 


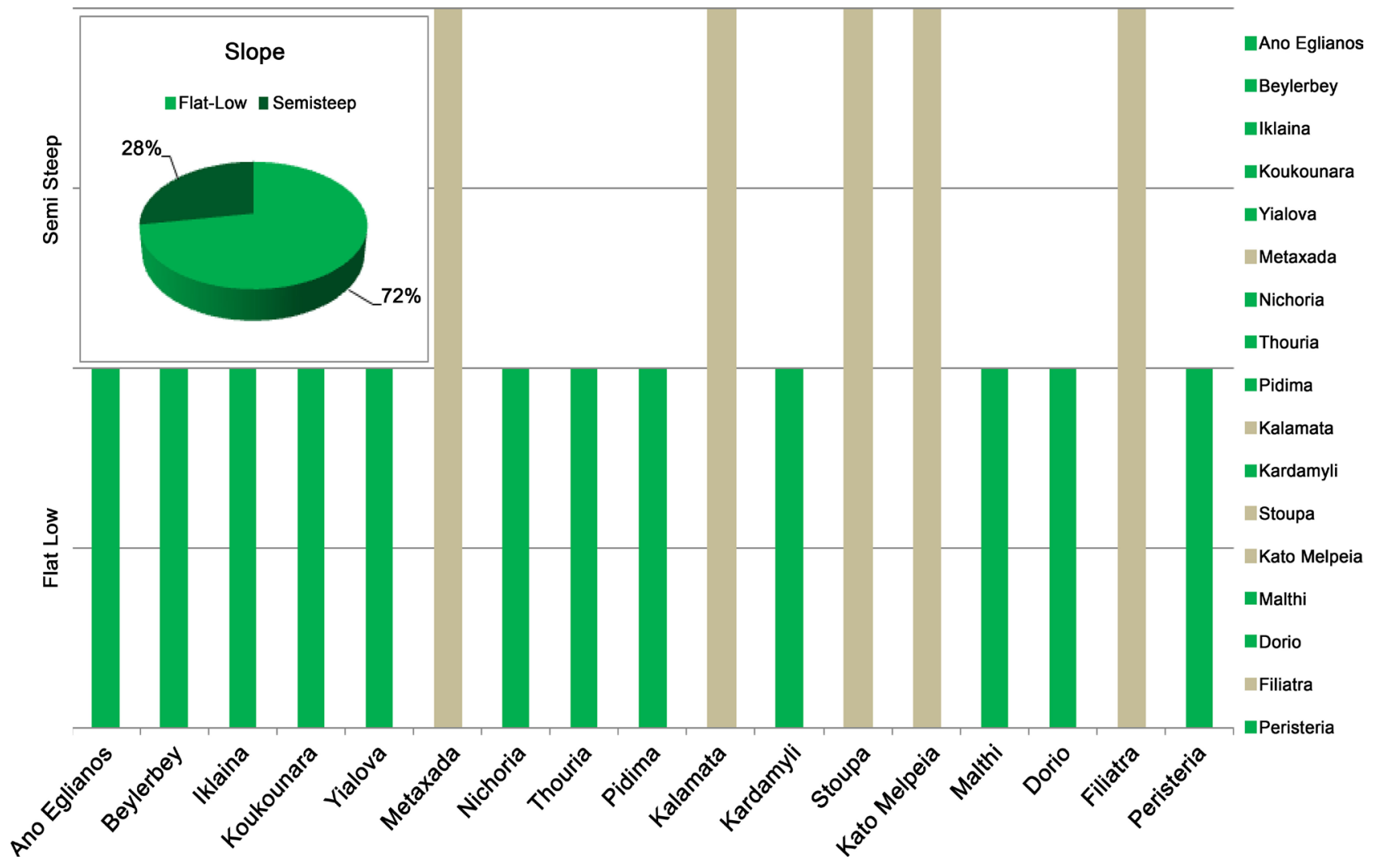

Figure 9. Association of slope with settlement location.

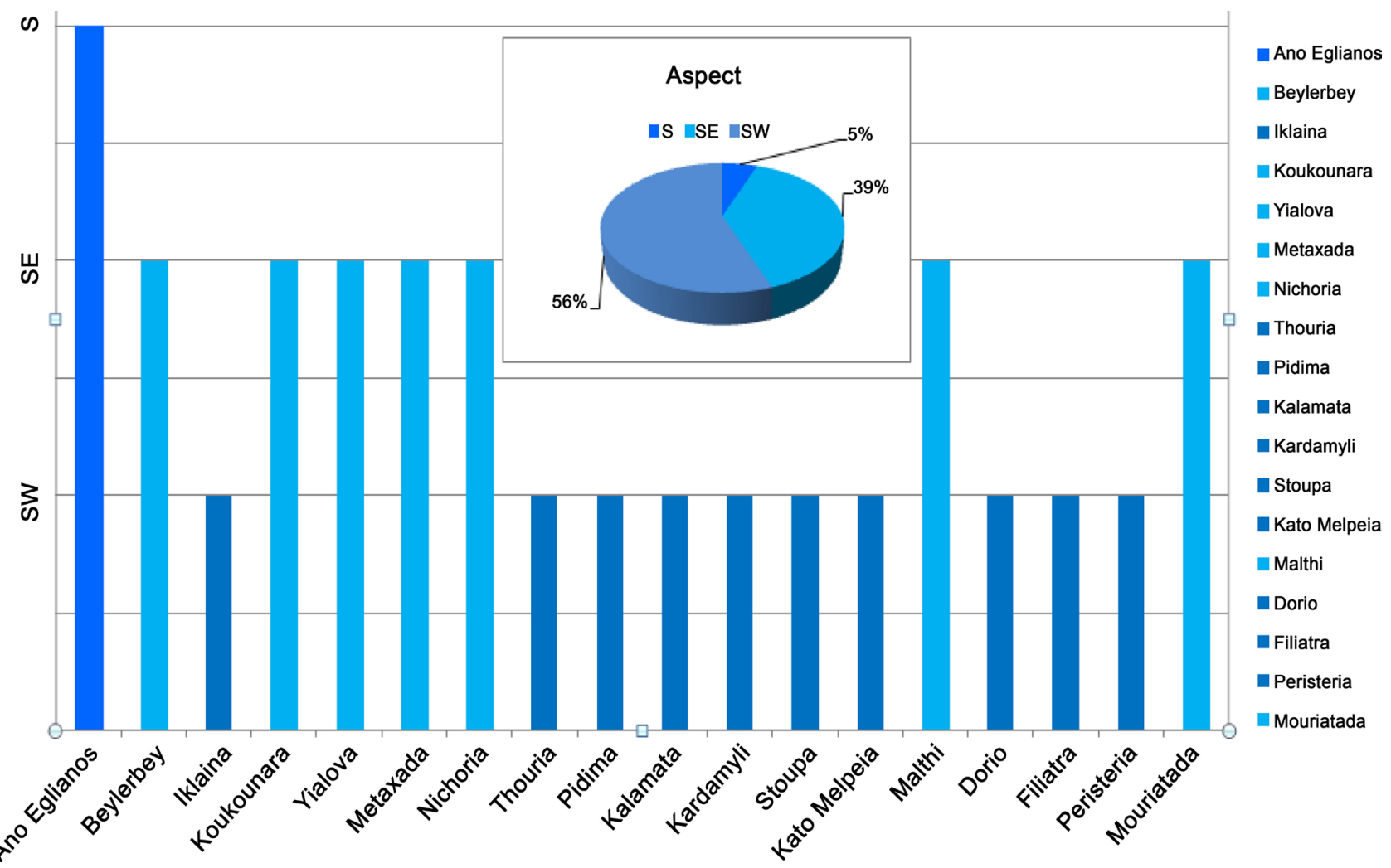

Figure 10. Association of aspect with settlement location. 


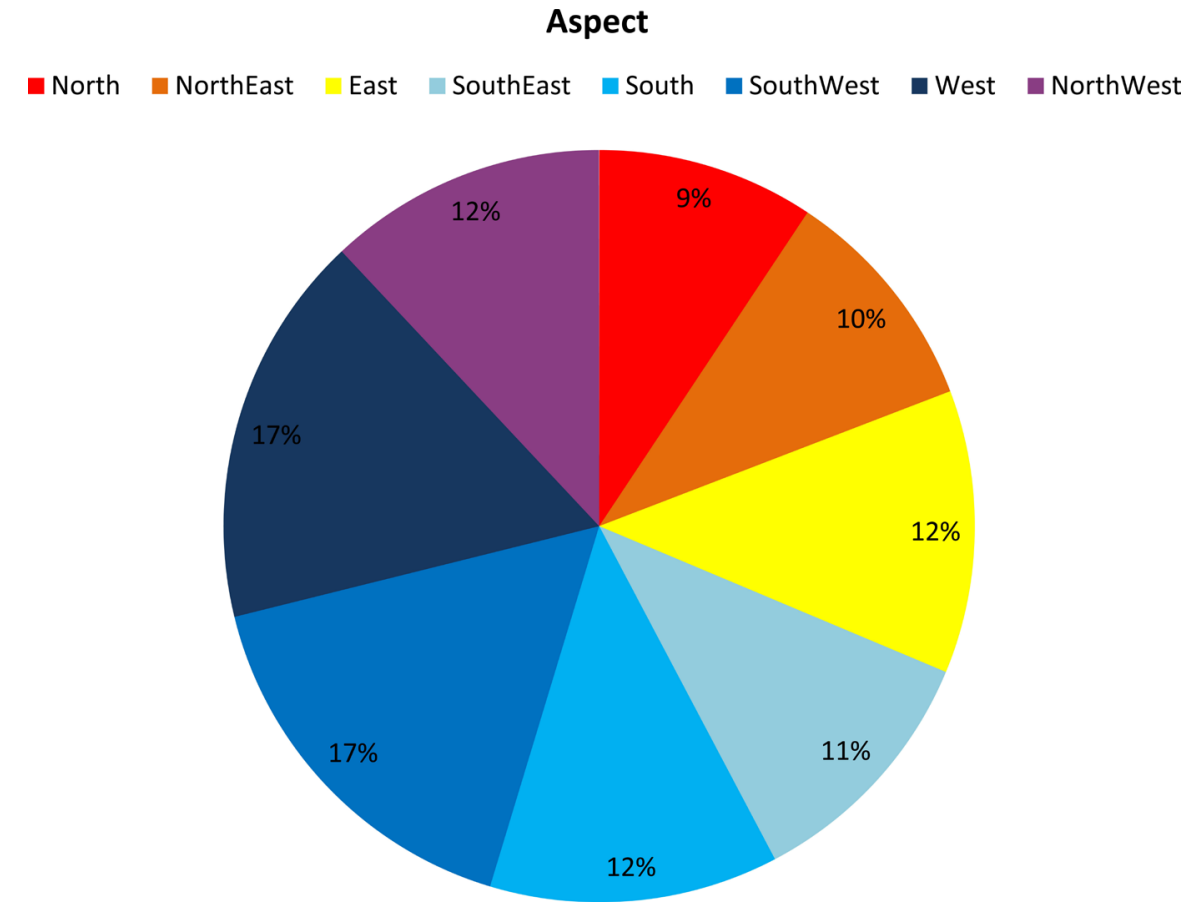

Figure 11. Aspect of the entire Messenia Prefecture.

occupation locations (Figure 12). Despite the fact that only $20 \%$ of the soil of the entire Messenia Prefecture consists of marls and sandstones (Figure 13), the overwhelming proportion of $83 \%$ of the settlements are built on these rocks and only $17 \%$ are located on alluvial deposits, since marls and sandstones are most suitable both for building and agriculture [26] [27] [28] (Figure $14 \&$ Table 2).

The marls can be subdivided into those occurring on the coastal terraces, where slopes are gentle and erosion is generally limited, and those located in the uplifted interior, where streams are deeply incised and erosion is severe. The soils on the marine terraces are generally well preserved and fertile but require irrigation for maximum productivity [23]. The alluvial deposits are materials without cohesion, in which the involvement of the block is usually small. They are predominantly found in riverbeds and are relatively recent deposits. The physical and chemical properties of the floodplain sediments make them the best areas for agriculture, provided there is sufficient water [23].

\subsection{Hydrographic Network}

The most significant factor in the selection of habitation sites since the beginning of human evolution was certainly the water supplies. Rivers and large streams are not just a source of clean drinking water; they serve as a source of food through fishing, as well as a transport route. Even today the most important cities in the world are located near rivers and more specifically in the points where rivers meet the sea, thus exploiting the water element to the maximum extent.

For the purposes of this study, Allocation Zones were created by the entities 


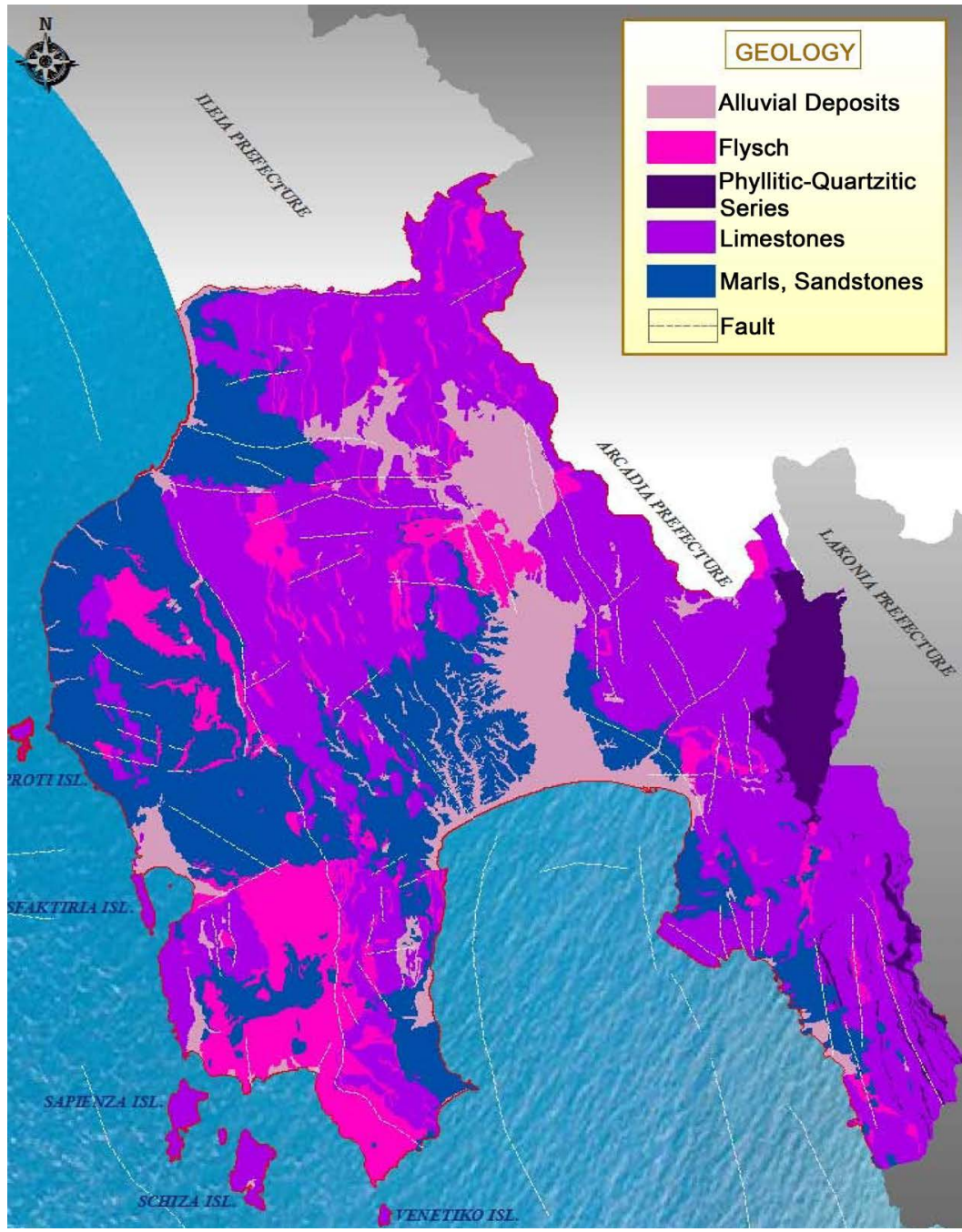

Figure 12. Geological map of the study area.

Geological Formation covering Messenia Prefecture (\%)

narls-Sandstones Alluvial $\square$ Limestones \#Flysch $\square$ Phyllite-Quartzite

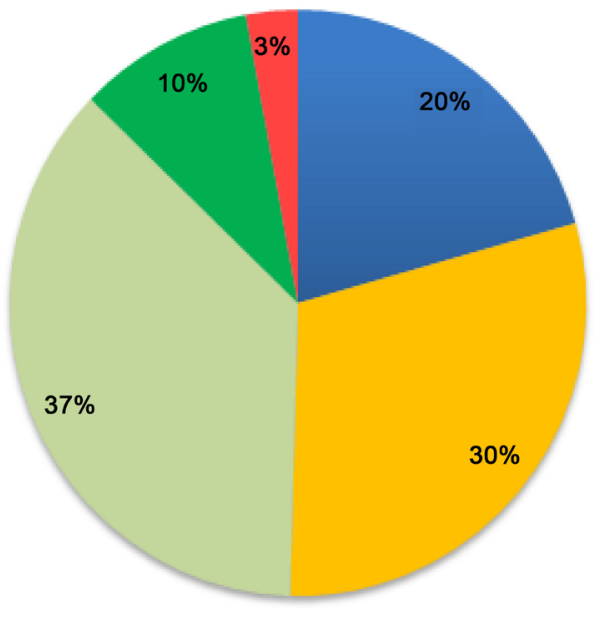

Figure 13. Geological formation covering the entire Messenia Prefecture. 


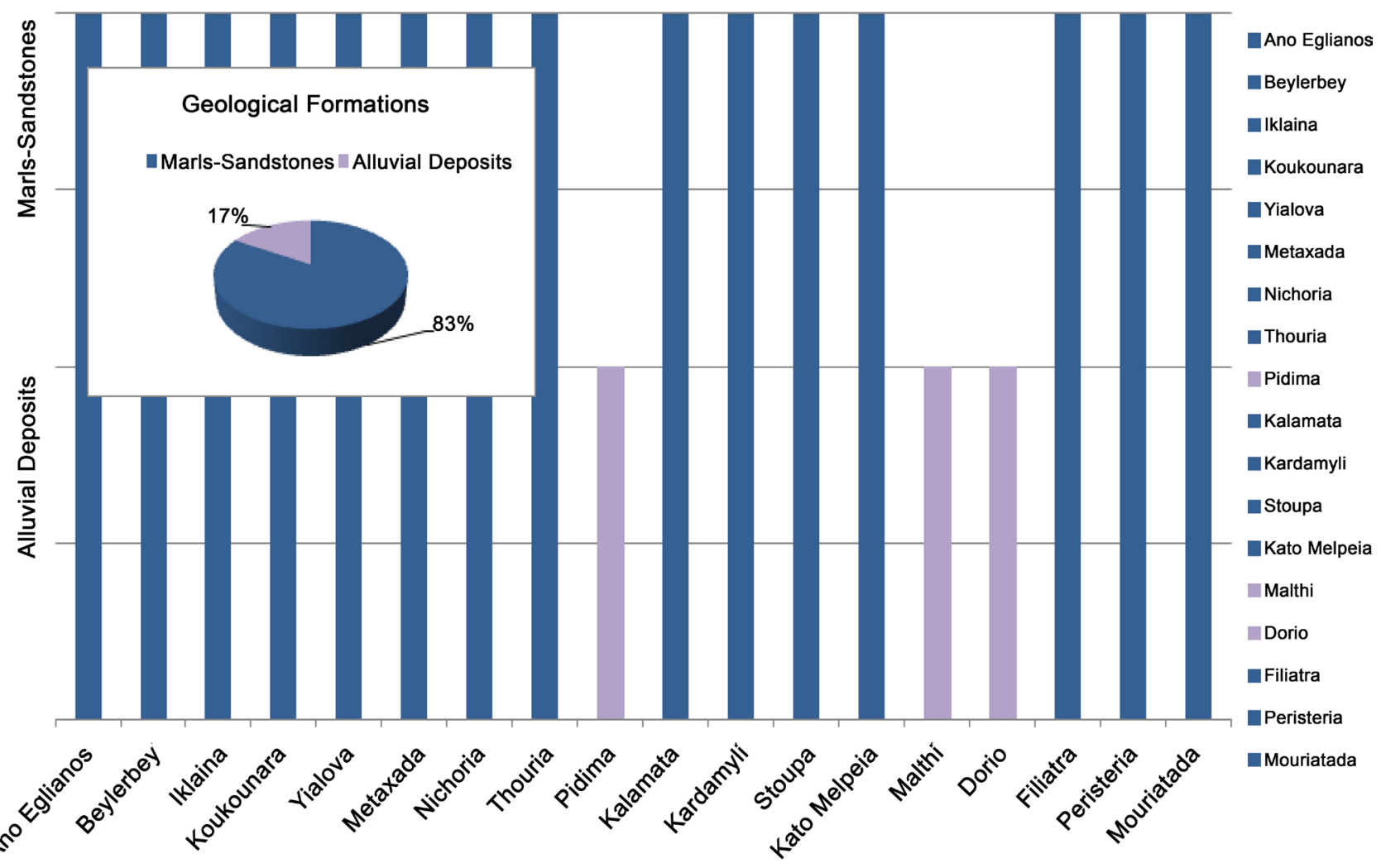

Figure 14. Association of geological formations with settlement location.

Table 2. Analysis index where altitude, aspect, the local geology and distance from water resources is given.

\begin{tabular}{|c|c|c|c|c|c|}
\hline Settlement & Elevation $(m)$ & Slope & Aspect & Geology & Hydro Distance (m) \\
\hline 1. Ano Eglianos & 192 & Low & South & Marls, Sandstones & 214 \\
\hline 2. Koryfasio-Beylerbey & 44 & Low & SouthEast & Marls, Sandstones & 82 \\
\hline 3. Iklaina & 166 & Low & SouthWest & Marls, Sandstones & 179 \\
\hline 4. Koukounara & 223 & Low & SouthWest & Marls, Sandstones & 38 \\
\hline 5. Yialova-Palaiochori & 52 & Low & SouthEast & Marls, Sandstones & 142 \\
\hline 6.Metaxada-Kalopsana & 442 & Semi-Steep & SouthEast & Marls, Sandstones & 69 \\
\hline 7. Rizomylos-Nichoria & 95 & Low & SouthEast & Marls, Sandstones & 83 \\
\hline 8. Thouria-Ellinika & 137 & Low & SouthWest & Marls, Sandstones & 73 \\
\hline 9. Pidima-Agios Ioannis & 29 & Low & SouthWest & Alluvial Deposits & 97 \\
\hline 10. Kalamata-Kastro & 75 & Semi-Steep & SouthWest & Marls, Sandstones & 155 \\
\hline 11. Kardamyli-Kastro & 23 & Low & SouthWest & Marls, Sandstones & 51 \\
\hline 12.Stoupa-Ancient Lefktro & 62 & Semi-Steep & SouthWest & Marls, Sandstones & 224 \\
\hline 13.Kato Melpeia-Krebeni & 317 & Semi-Steep & SouthWest & Marls, Sandstones & 118 \\
\hline 14. Malthi-Gouves & 160 & Low & SouthEast & Alluvial Deposits & 18 \\
\hline 15. Dorio-Kontra & 287 & Low & SouthWest & Alluvial Deposits & 290 \\
\hline 16. Filiatra-Ayios Christoforos & 213 & Semi-Steep & SouthWest & Marls, Sandstones & 61 \\
\hline 17. Myron-Peristeria & 102 & Low & SouthWest & Marls, Sandstones & 81 \\
\hline 18. Mouriatada-Elliniko & 399 & Semi-Steep & SouthEast & Marls, Sandstones & 108 \\
\hline
\end{tabular}


through the Allocation option. This feature identifies the tiles closest to each reference object and associates parts of the space with the closest reference objects. This process was carried out with the purpose of creating Buffer Zones per 100 meters from the rivers to the Centers under consideration. In this way, the exact distance from the hydrographic network (including the rivers and the largest streams of the Prefecture of Messinia) was defined in a straight line.

Based on the results of Figure 15, there is a high affinity between the existence of rivers and streams and the location of settlements, as expected. As we can see in (Figure 16), all settlements are located in a short distance from a river or a stream $(0-300 \mathrm{~m})$.

\subsection{Random Testing via PCA Analysis and G.I.S.}

A number of statistical tests have been carried out in order to further examine whether the observed patterns are random or not. We used three random spot sampling methods in ARCGIS software eliminating any human intervention risk with the sample of our 10 larger settlements. With the first method we created an equal number of samples on the map and compared the results of 10 random points on the map. For the second method a larger number of samples was requested, and more specifically five times the initial one (50 random points on the map). From this sample, the 10 best correlated values were isolated and the

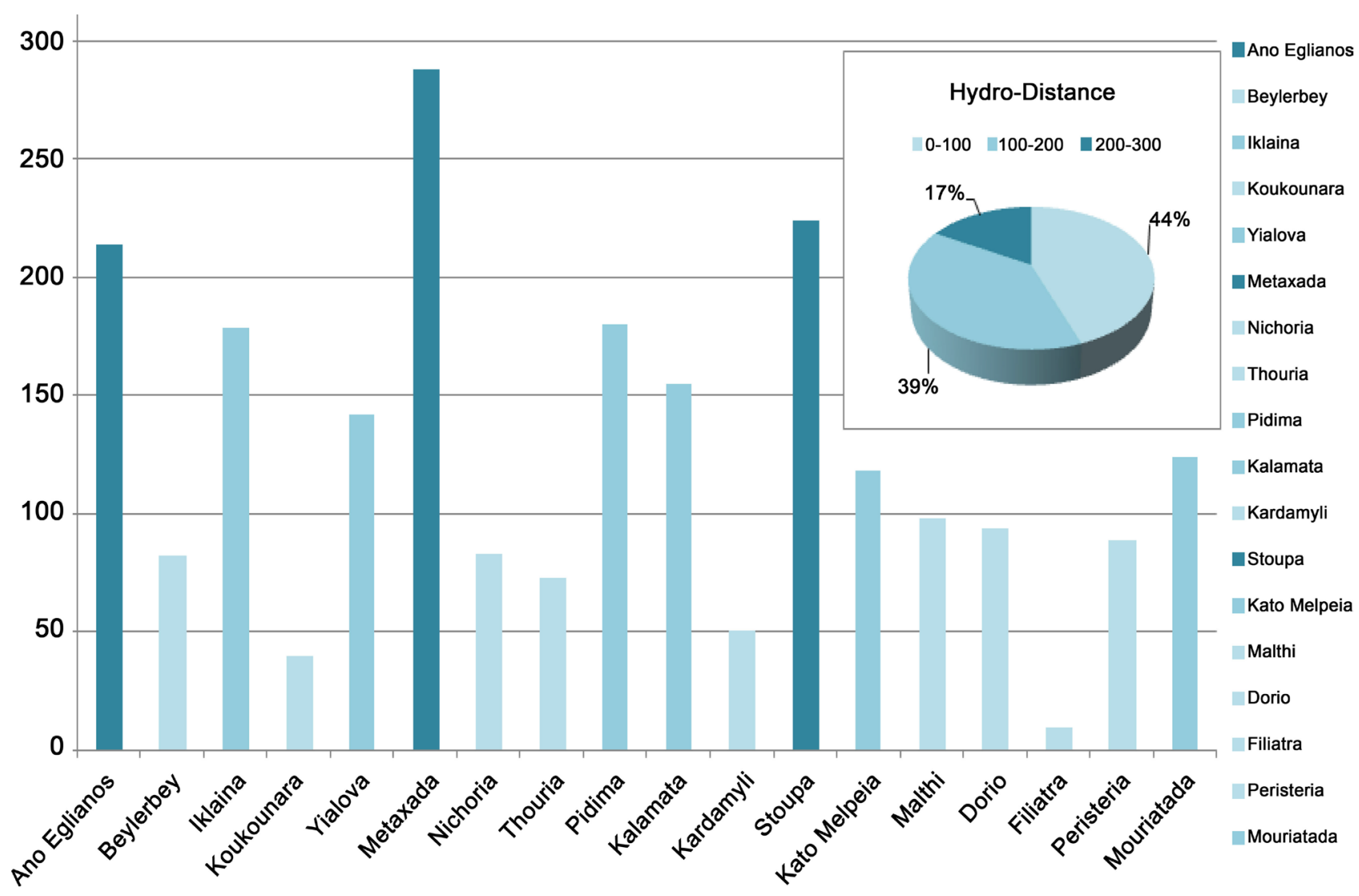

Figure 15. Association of hydrographic network with settlement location. 


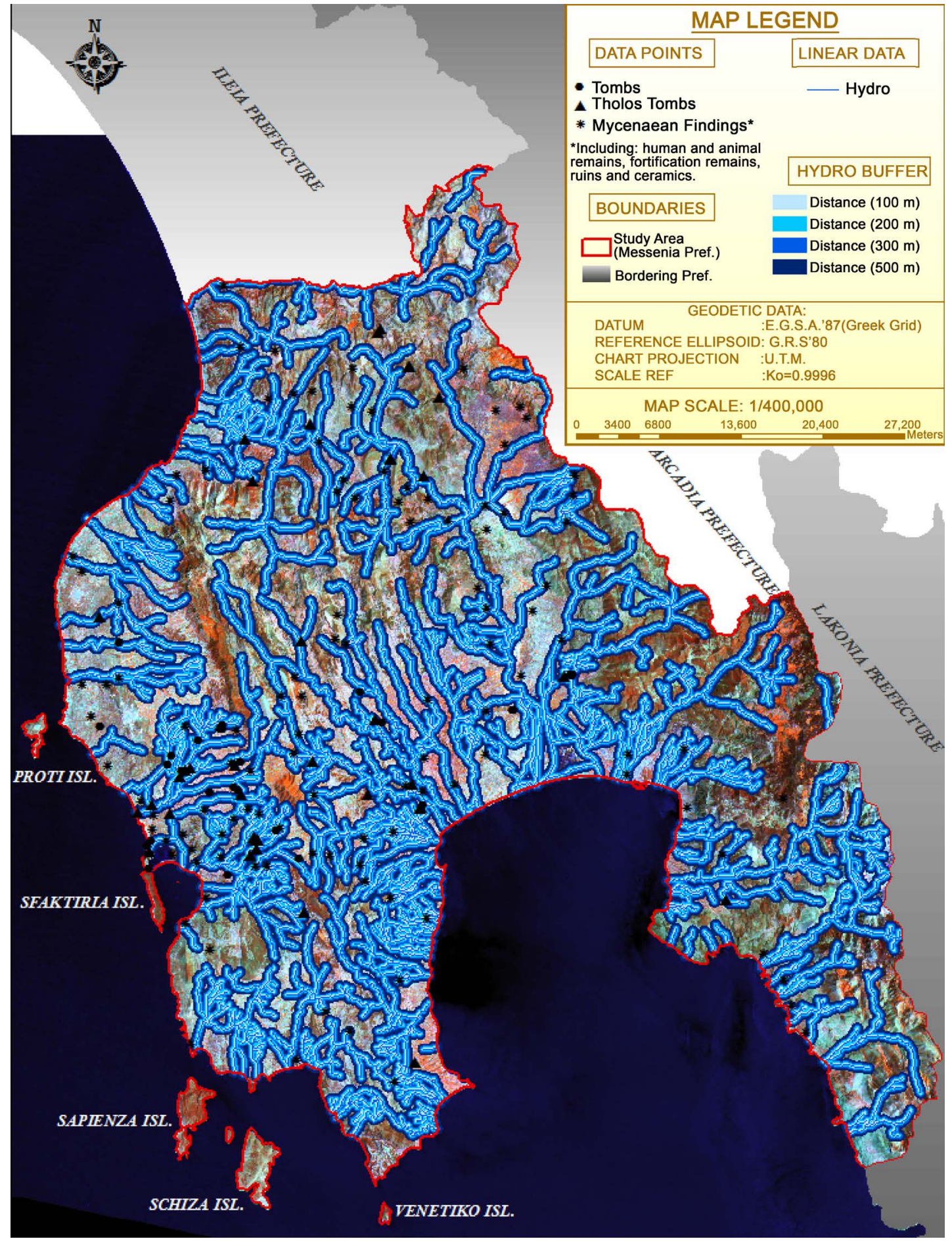

Figure 16. Hydro buffer zones map.

comparison of accuracy with actual data repeated. Finally, in the third case a 10 -fold number of random samples (100 random points on the map), was used. The process of optimal isolation of the 10 best correlated values was repeated and the comparison of accuracy with actual data, that of Centers' prices, was repeated. In this process, it was proven that the correlation of the factors of the 
actual values of the Centers is not simply random, but even in a 10-fold sample number (using the selection of the best sample values) the correlation of the actual values is better than the probability of choosing the Mycenaean Residential by chance and not based on specific factors.

For testing the process, the Principal Component Analysis (PCA) method was used after the calibration of the parameters. In conclusions, it is observed that the actual values, the values of Settlements, form a very well defined group which is around the ideal value (IDEAL). On the other hand, Random points diverge considerably from each other, but also from the ideal value (IDEAL). In general the random points do not show any sort of correlation of the data even in the case of 50 and 100 random points (Figures 17-19).

\section{Discussion and Conclusions}

In this paper the Geocumulative versus Habitation approach $(\mathrm{GCH})$ was applied to examine patterns in settlement location selection in Messenia during the Mycenaean era. The study was confined to the eighteen largest settlements that have been identified, which correspond to the two upper tiers of settlement hierarchy

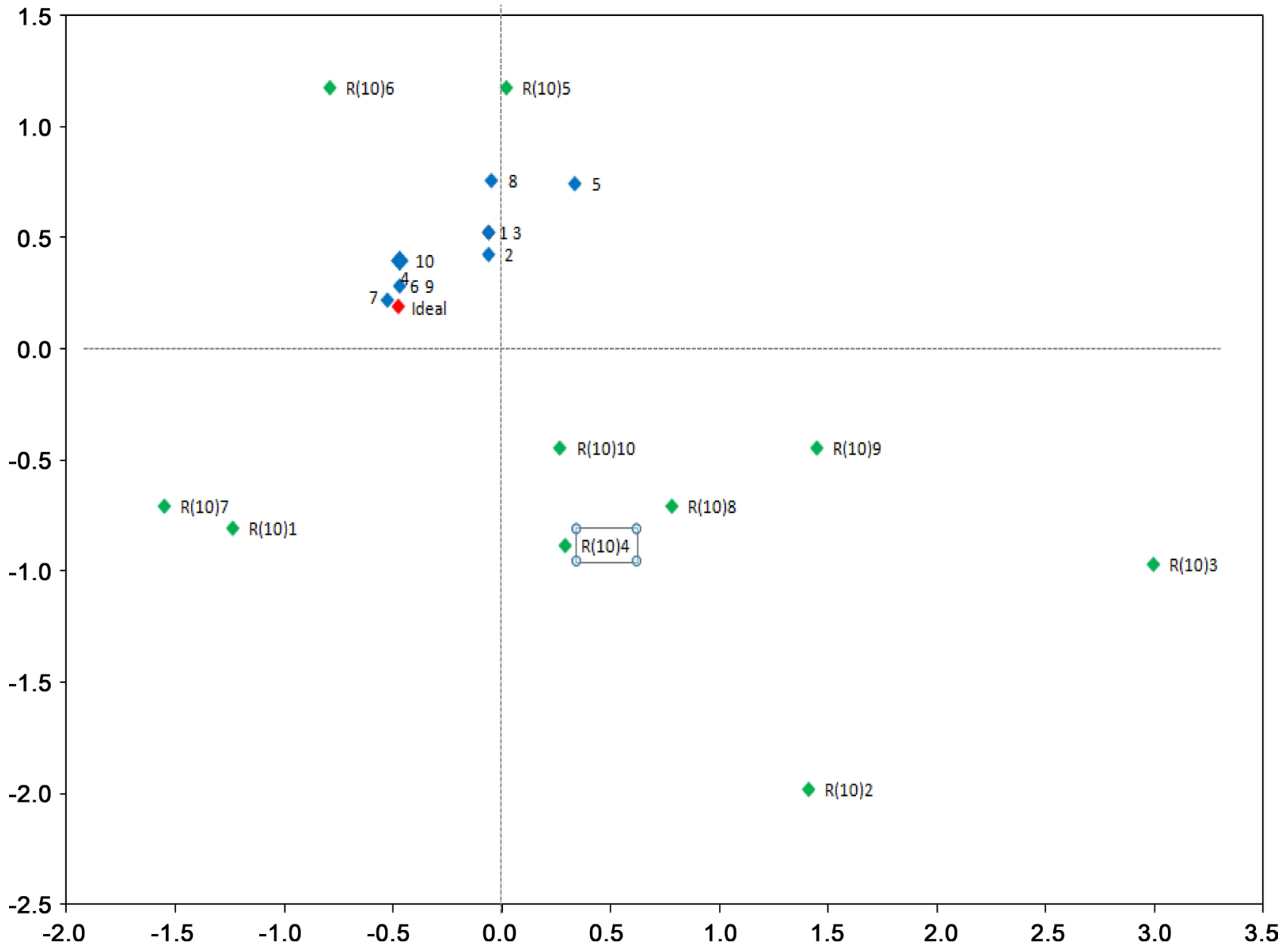

Figure 17. PCA test 1: a ten to ten settlement test. 


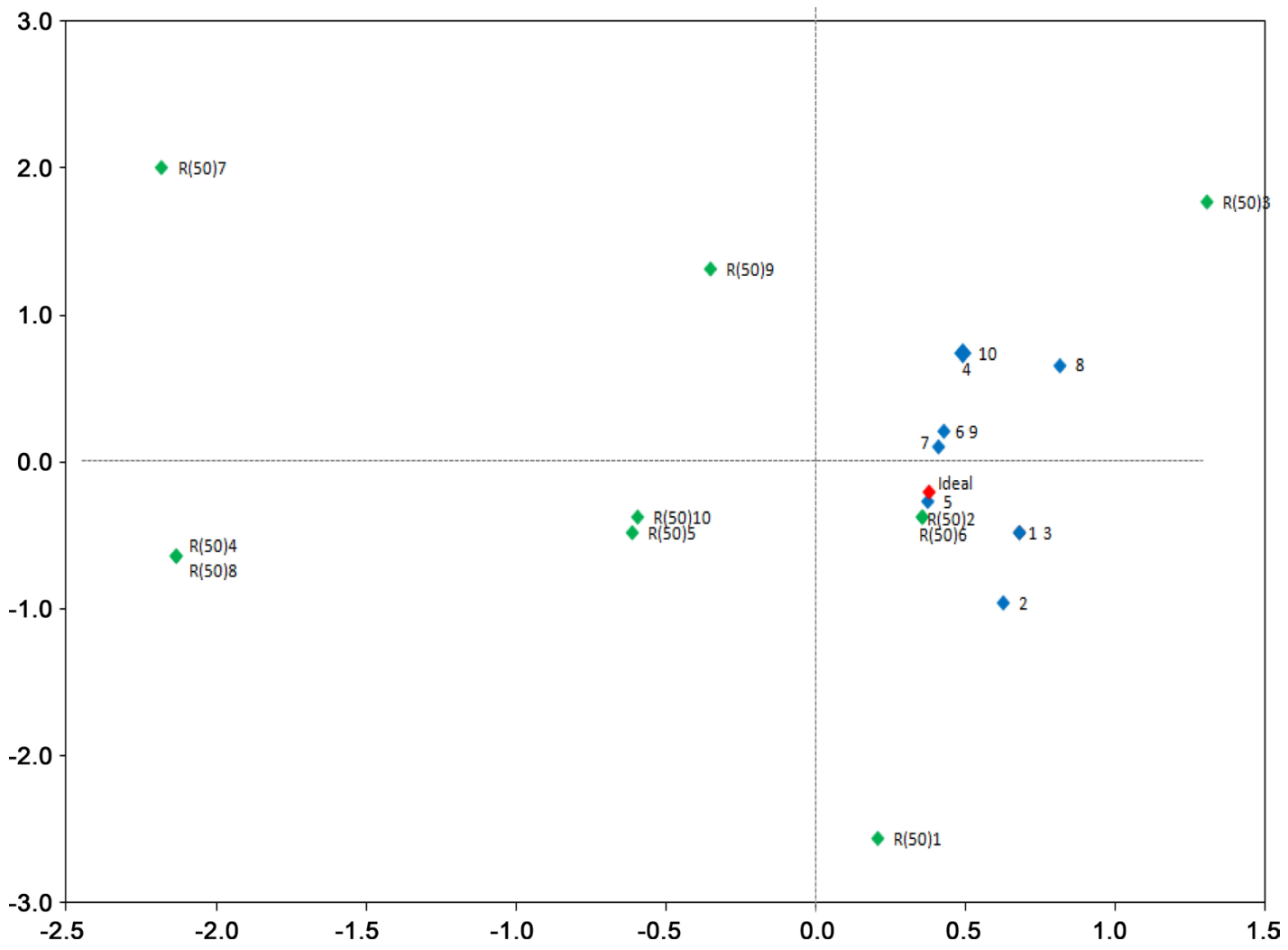

Figure 18. PCA test 2: a ten to fifty settlement test.

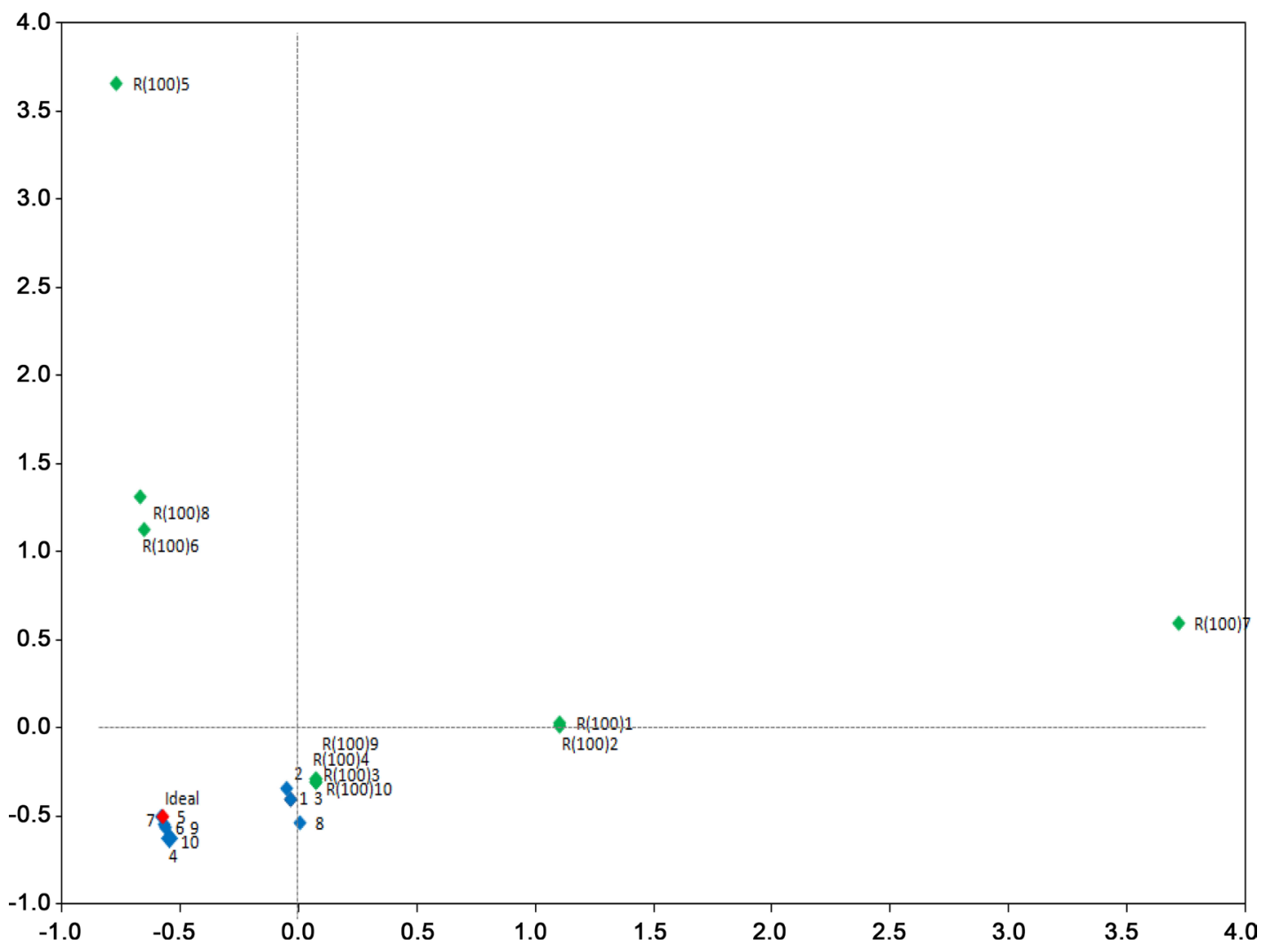

Figure 19. PCA test 3: a ten to one hundred settlement test. 
of that time. This first attempt to thoroughly examine the location of the settlements of the Mycenaeans demonstrates that their criteria greatly resembled modern habitation criteria. The validity of the outcomes of the GIS data results was evaluated via statistical analysis using P.C.A. (Principal Component Analysis).

The majority of the sites under study (83\%) are located either on flat ground or on small hills (altitude of $0-300 \mathrm{~m}$ ), with a very small sloping grade, thus combining easy access to the surrounding land with defensibility. Also all the settlements are on hills and they could also function as observatories due to their high radius of visibility. Moreover, despite the mild weather conditions of the region, all settlements have a southern orientation, providing maximum sunshine as well as protection from the northern winds at the same time.

Regarding geology, the vast majority (83\%) of the settlements under study are located on marls and sandstones. Both these types of rock are very well suited for agriculture and for the provision of building material. It should be emphasized in this respect that marls and sandstones cover only $20 \%$ of the Messenian ground surface.

Soil versatility is an extremely critical factor for the structural needs in ancient societies. It is easy to see that the greater the plasticity of the soils, the cost of building and transporting materials gets lower. The fact that all of the examined Centers are located in such areas is particularly important and suggests that the choice of position could not have been random.

Finally, water supply is also a significant parameter in settlement location, since all settlements are located next or very close to rivers or streams (at a distance of up to $255 \mathrm{~m}$ ), thus ensuring easy access to water resources.

In conclusion, the GCH approach suggests that settlement location in Mycenaean Messenia was far from random and it followed specific environmental criteria. The vast majority of the Mycenaean settlements are: 1) located on small hills with low slopes, 2) the main geological features are marls and sandstones, 3) the aspect of the ground is south, 4) located very close to water resources.

This is a significant finding because it clearly shows that 4500 years ago (well before the peak of Greek Classical Civilization), Mycenaeans were aware of the bioclimatic and environmental factors which improved their living conditions. Future application of this hypothesis to other Mycenaean regions is needed to confirm the concluding remarks of the present study. However, the results of this study can offer significant insight regarding the Mycenaean society for archaeologists and historians. The vast majority of the available information for Mycenaeans comes from the Linear Tablets and the excavations of the relevant sites. The new information provided by the use of GCH approach offers an overview of all sites located in a large region, as well as the surrounding landscape, without disregarding the unique characteristics of each individual site. Therefore, combined with archaeological record, it can improve our understanding of important parameters of the Mycenaean society such us the connectivity of sites, agricultural capacity and the defensive strategy. Finally, the present study can be the basis of 
a Prediction Model for the selection of Mycenaean habitation sites. The identification of areas which are characterized by the conditions that were considered preferable by Mycenaeans, can assist in the determination of the areas where habitation centers are most likely to be found.

\section{References}

[1] Mehrer, M.W. and Wescott, K.L. (2006) GIS and Archaeological Site Location Modeling. CRC Press Taylor and Francis, Boca Raton.

[2] Wheatley, D. and Gillings, M. (2002) Spatial Technology and Archaeology-The Archaeological Applications of GIS. CRC Press Taylor and Francis, Boca Raton. https://doi.org/10.4324/9780203302392

[3] Tsiafakis, D. and Evagelidis, V. (2006) GIS as an Interpretative Tool in Greek Archaeological Research. GISRUK, Nottingham.

[4] Gupta, N. and Devillers, R. (2016) Geographic Visualization in Archaelogy. Journal of Archaelogical Method and Theory, 1-38.

[5] Sarris, A. and Déderix, S. (2012) GIS for Archaeology and Cultural Heritage Management in Greece. Quo Vadis? In: Zacharias, N., Ed., 3rd Symposium Archaeological Research and New Technologies, University of the Peloponnese, Kalamata, 9-22.

[6] Dederix, S. (2017) Communication Networks, Interactions, and Social Negociation in Prepalatial South-Central Crete. American Journal of Archaeology, 121, 5-37. https://doi.org/10.3764/aja.121.1.0005

[7] Alexakis, D.D., et al. (2013) Natural and Human Hazard Assessment of the Archaeological Sites of Paphos Area (Cyprus) with the Use of Remote Sensing and GIS. International Congress of the Geological Society of Greece, Chania, 5-8 September 2013, 35 .

[8] De Reu, et al. (2011) Measuring the Relative Topographic Position of Archaeological Sites in the Landscape, a Case Study on the Bronze Age Barrows in Northern Belgium. Journal of Archaeological Science, 38, 3435-3446. https://doi.org/10.1016/j.jas.2011.08.005

[9] Ladefoged, et al. (2011) Agricultural Potential and Actualized Development in Hawai'i. An Airborne Lidar Survey of the Leeward Kohala Field System (Hawai'i Iisland). Journal of Archaeological Science, 38, 3605-3619. https://doi.org/10.1016/j.jas.2011.08.031

[10] Mlekuž, D. (2013) Time Geography, GIS and Archaeology. In: Contreras, F. and Melero, F.J., Eds., 38th Conference on Computer Applications and Quantitative Methods in Archaeology, Archaeopress, Oxford, 443-445.

[11] Rinaudo, F., Agosto, E. and Ardissone, P. (2007) GIS and WEB-GIS, Commercial and Open Source Platforms: General Rules for Cultural Heritage Documentation. 21 th International CIPA Symposium, Athens, 1-6 October 2007, 625-630.

[12] Liko, S. (2012) Second Order Centers and Regional Integration in the Late Bronze Age Aegean (diss.). Florida State University Arts and Science, Tallahassee, 15-16, 64.

[13] Simpson, H.R. (2014) Mycenaean Messenia and the Kingdom of Pylos Philadelphia. INSTAP Academic Press, Pennsylvania.

[14] Bintliff, J.L. (1977) Natural Environment and Human Settlement in Prehistoric Greece: Part II. British Archaeological Reports. 
[15] Cosmopoulos, M.B. (2006) The Political Landscape of Mycenaean States: A-pu $\mathrm{pu}_{2}$ and the Hither Province of Pylos. American Journal of Archaeology, 110, 205-228.

[16] Davis, J.L., Alcock, S.E., Bennet, J., Lolos, Y.G. and Shelmerdine, C.W. (1997) The Pylos Regional Archaeological Project: Part I. Hesperia, 66, 391-494. https://doi.org/10.2307/148395

[17] Bennet, J. (1999) Pylos: The Expansion of a Mycenaean Center. In: Galaty, M. and Parkinson, W.A., Eds., Rethinking Mycenaean Palaces. New Interpretations of an Old Idea, The Cotsen Institute of Archaeology, Los Angeles, 9-18.

[18] Zavadil, M. (2013) Monumenta, Studien zu mittel-und spathelladischen Grabern in Messenian. Österreichische Akademie er Wissenschaften, Wien.

[19] Zavadil, M. (1995) Bronzezeitliche Tumuli den Westpeloponnes. unpublist Diploma Thesis, Universitat Wien, Wien.

[20] Simpson, H.R. (1981) Mycenaean Greece, Park Ridge, New.

[21] Banou, E. (2012) Messenia: The Prehistory in Messenia: Contributions to Its History and Culture. Papazisis Publications, University of the Peloponnese, Athens, 13-75. (In Greek)

[22] Morris, M. (2002) Soil Science and Archaeology: Three Test Cases from the Minoan Crete. Prehistory Monographs, INSTAP Academic Press, Philadelphia.

[23] Troeh, F.R. and Thomson, L.M. (2005) Soils and Soil Fertility. Blackwell, Ames.

[24] McDonald, W.A. and Rap, G.R. (1972) The Minnesota Messenia Expedition. Reconstructing a Bronze Age Regional Environment. Minneapolis.

[25] Demek, J. (1972) Manual of Detailed Geomorphological Mapping. Academia, Prague, $344 \mathrm{p}$.

[26] Tseles, D., Finos, D. and Gulta, M. (2011) Integrated System of Agricultural Land Management using GIS. GSRG Program: Scientific Support for Young Farmers, TEI of Piraeus, 9-13. (In Greek)

[27] Tsafou, K. and Hadjiharistou, E. (2007) Technological Geological Map of the Peloponnese using GIS. University of Patras, Department of Applied Geology and Geophysics, Patras, 53-72. (In Greek)

[28] Hunt, R.E. (1984) Geotechnical Engineering Investigation Manual. McGraw-Hill, New York, 201-216. 